\title{
ONKO OPPIMINEN ELÄMÄNKOKEMUSTA?
}

\author{
Raimo Silkelä (1999) \\ Persoonallisesti mer- \\ kittävät oppimiskoke- \\ mukset. Tutkimus luo- \\ kanopettajaksi opiske- \\ levien oppimiskoke- \\ muksista. Joensuun yli- \\ opiston kasvatustieteellisiä \\ julkaisuja 52 .
}

Raimo Silkelän tutkimus on mielenkiintoinen. Se herättää ajattelemaan määräytyneisyyden ja vapauden suhdetta aikuisen ihmisen elä- mänkaaressa. Esittelen ensiksi nämä teoksen lukukokemukseen liittyneet pohdinnat. Kuvittelen postmodernisti ajattelun juoksuni selostamisen vaivan väärtiksi - lukijaa kiinnostavaksi. Tuohon ilmaisuun on sisällytetty paradoksi - mikä, sen päätelkööt lukijat. Vasta pohdintojeni jälkeen siirryn perinteisemmin arvioimaan Silkelän tutkimusta.

\section{Aikuiskoulutuksen} sosiologia on Suomessa ollut suosittu tutkimusalue. Ihmis- tieteiden lingvistisen käänteen myötä on myös sosiologiatiede suuntautunut kohden 'pientä ihmistä'. Aikuisuuden sosiologiasta on tutkimustietoutta runsaasti saatavilla. Ihmisten elämänkertojen muotoutumisen yhteiskunnalliset sidonnaisuudet tunnetaan hyvin. Postmodernin hengen mukaisesti korostetaan kuitenkin ihmisen vapautta itse hahmottaa ja määrittää paikkansa. Jos ei muuten, niin ainakin elämäkertaan kohdistuvana takautuva- 
na narratiivisena vapautena.

\section{Sosiaalisten rakenteiden} runnovuus on tänä 'yksilöyrityksen' aikakautena lähes pannaan julistettu asia. Olisiko aika pohtia, mihin tarvitaan voimakkaasti yksilön psykologiseen vapauteen uskovaa ideologiaa, joka saa kiteytyneen ilmiasun kahtaalla: postmodernissa sosiologisessa keskustelussa sekä oppivan organisaation liturgiassa? "Missä eniten rehellisyyttä vakuutetaan, siellä sinut varmiten petetään" -sananlasku tulee jotenkin mieleen, kun näitä asioita nyt pohdin.

\section{Aikuisten oppimisen} tutkimisen mielenkiinto on viime aikoina selvästi suuntautunut arkielämän oppimiseen. On jäsennetty ihmisten arkielämää oppimisen ympäristönä. On luokiteltu oppimista virittäviä ja suuntaavia arkielämän tekijöitä. Näissä jäsennyksissä välähtelevät eri elämänalueet. On havaittu, että arkipäiväoppimista tapahtuu ystävien, perheen, vapaaajan, median, kulutuksen jne piirissä toimittaessa. Ja paljon pidemmälle ei ole yleensä päästykään. Mitä nyt tekstin joukkoon on 'postmodernisti' heitelty mukaan sopivia lainauksia sopivilta tekijöiltä. Baumanit, ziehet, giddensit, beckit ja lashit vilahtelevat lähteinä. Samalla fakta ja fiktio rupeavat yleensä menemään sekaisin.

\section{Oppimistapahtuman}

kuvaus, jäsennys ja analyysi näin vaikuttaa pääsääntöisesti kadonneen pesuveden mukana. On toki kiinnostavaa tietää, missä kaikkialla tapahtuu oppimista. On kiintoisaa op- pia aiheeseen liittyvä postmoderni sosiologinen liturgia. Tärkeää olisi kuitenkin näiden ohella, tai edes lisäksi, myös tietää, miten oppiminen arkielämässä tapahtuu.

\section{Miten -kysymykseen}

vastaaminen edellyttää oppimis-psykologisen ja persoonallisuuspsykologisen teorianmuodostuksen hallinnan. Arkielämän oppimistapahtuma ei nimittäin ole psykologisesti yksinkertainen tilanne. Ihmisen psyykeen kerroksellisuus, kerrosten eriaikaisuus ja ne tuottaneiden oppimismekanismien systemaattinen eroavuus aiheuttavat tutkimuksellisen haastavuuden. Arkipäivän oppiminen on ensisijaisesti sensitaatiota, habituaatiota, klassista ja välineellistä ehdollistumista sekä sosiaalista oppimista sen eri muodoissa.

\section{Nämä oppimisen}

mekanismit puuttuvat nykyisistä aikuispsykologisista tutkimuksista. Ne eivät korosta ihmisen psyykeen vapautta, vaan pikemmin sen sidonnaisuutta, ainutkertaista ja pysyvää yhteiskunnallis-historiallisesta kontekstista determinoitumista. Olisiko mahdollisesti niin, että determinaatiota korostava näkökulma ei yksinkertaisesti myy! Ja jos ei myy, se on tieteellisesti tarpeeton, koska se ei voi olla tosi.

\section{Kliseisissä post-}

moderneissa tutkimuksissa sitä vastoin korostetaan aikuisen ihmisen vapautta itse muovata oman tajuntansa sisältö ja rakenne tyyliin: 'pikkasen vaeltelen maailman turuilla identiteettiäni luomassa'. Sosiologiatieteen avulla kyetään hyvin kuvaamaan reunaehtoja, yhteiskunnallis-historiallisia todellisuuksia, joiden sisällä ihmisen psyykeen muodostuminen tapahtuu. Psyykkisen tapahtumisen ja oppimisen prosesseja tutkittaessa on sitä vastoin edelleen psykologiatiede paikallaan; asia, joka vaikuttaa monen mielistä unohtuneen. Baumanit, ziehet, giddensit ja lashit (yms) ovatkin yllättäen myös aikuispsykologisen alueen auktoriteetteja!

On selvää, että edellä nimeämäni oppimismekanismit eivät edellytä korkeatasoista tietoisuutta. Ne ovat kuitenkin oppimismekanismeja, joiden avulla ihmisen tyyli, olemus, laatu ja luonne tuotetaan - välineitä, joiden avulla ihmisen yhteiskunnallista luonnehahmoa muovataan. Näiden keskeisten oppimismekanismien avulla avautuu vastaus kysymykseen siitä, miten tuotetaan työmarkkinoiden kovasti kaipaama 'hyvä tyyppi'. Arkielämän oppimisen syvälliselle psykologiselle tutkimukselle on siis kaikesta huolimatta vankka tilaus jo olemassa.

\section{Raimo Silkelän tutkimus} käsittelee nimensä mukaisesti persoonallisesti merkittäviä oppimiskokemuksia. Tutkimuksen kohderyhmänä olivat luokanopettajaksi opiskelevat, joita haastateltiin useampaan otteeseen neljän vuoden aikana. Haastateltujen lukumäärä eri haastattelukerroilla vaihteli siten, että vähimmillään haastateltiin 8 ja enimmillään 18 opiskelijaa. Persoonallisesti merkittävät oppimiskokemukset olivat symbolisia kasvukokemuksia, tasankokokemuk- 
sia, joskus myös huippu- ja laaksokokemuksia, elämänkulun siitymävaiheita, elämän tarkoitus- ja hljentymiskokemuksia, vapaa-aikana ja työssä tapahtuneita oppimiskokemuksia.

\section{Tutkimuksessa}

tarkastellaan merkittävien oppimiskokemusten kontekstia (missä oppiminen tapahtuu) monipuolisesti. Teoreettisena viitekehyksenä on fenomenologinen ja semioottinen näkökulma. Viitekehyksenä se ei ollut mielestäni paras mahdollinen. Tässäkin tutkimuksessa varsinaisen oppimistapahtuman huolellinen teoreettinen erittely jäi puuttumaan (miten oppiminen tapahtuu). Erilaisten oppimisen muotojen tunnistaminen ja problematisointi olisi ollut paikallaan. Paikallaan olisi ollut myös pohtia, millä persoonallisuuden tasolla merkittävä oppimiskokemus tapahtuu, mitä eri persoonallisuuden kerroksia se koskettaa, mikä yksilössä muuttuu; vai voisiko juuri muuttumattomuus ilmaista merkittävän oppimiskokemuksen esiintymisen tai läsnäolon.

\section{Arkielämän oppimista} tutkittaessa on aiemmin oletettu pääsääntöisesti oppimiskokemus vaikutuksiltaan myönteiseksi. Ilmeisesti iso osa arkipäivän oppimisesta on kuitenkin sellaista oppimista, jossa yksilö 'oppii kaapin paikan'. Kielteiseksi koetut oppimiskokemukset ovat nykyisin onneksi jo tutkimuksellisen silmälasin alla, näin myös Silkelän tutkimuksessa.

\section{Tutkimuksellisesti}

käsittelemättömät isot ongel- mat ovatkin toisaalla. On aika vankkoja teoreettisia perusteita olettaa, että ainakin merkityksellisimmät kielteiset oppimiskokemukset pyrkivät pysymään/olemaan/painumaan tiedostamattomiksi toiminnan reunaehdoiksi. On myös vankkoja perusteita olettaa, että merkittävä osa arkipäivän oppimisesta on nimenomaan tiedostamatonta hioutumista - esimerkiksi mainonta perustuu suurelta osin tietoisuuden sivussa tuotettuun emotionaaliseen oppimiseen. Entäpä sitten persoonallisuuden piirteen oppiminen - mitenköhän esimerkiksi sinnikkyys tai lannistamattomuus opitaan? Ja miten nämä opitaan: yhdestä oppimiskokemuksesta vai toistuvien oppimiskokemuksien sarjasta? Tarvitseeko yksilön tiedostaa oppimaansa, jotta häneen syntyisi piirre, joka voidaan nimetä sinnikkyydeksi? Näitä asioita ei aikuispsykologisessa tutkimuksessa kovin usein sivuta - ei myöskään Silkelän tutkimuksessa.

\section{Arvioni Silkelän}

tutkimuksen aikuispsykologisesta painoarvosta on ollut tähän asti kovin kriittinen. Silkelän tutkimuksen ansiot ovat jääneet katveeseen. Työ täyttää paikkansa sosiaaliseen tilaukseen vastaajana. Ja miksi? (1) Tutkimuksen empiirinen aineisto on huolellisesti kerätty ja yksityiskohtaisesti esiin kirjoitettu. (2) Työn empiirinen osa saa lukijansa pohtimaan syvällisesti inhimillisen kasvun kirjoa - tarkempaan tarkasteluun valitut tutkimushenkilöt piirtyvät eläväisesti lukijan tajuntaan (3) Tutkimukseen on kiintoisasti liitetty elämänkaaripyko- logisen näkökulman ituja. (4) Tutkimuksesta avautuu sellaisia näköaloja, joiden avulla voidaan vastaavien tutkimusten tulevaa kysymyksenasettelua jo ennakkoon tarkentaa.

(5) Tutkimus auttaa myös rajaamaan pois näkökulmia, jotka eivät vaikuta merkityksellisiä oppimiskokemuksia tarkasteltaessa hedelmällisiltä. (6) Tutkimus on myös didaktisesti kiinnostava. Se osoittaa, että yksittäisenkin oppimistapahtuman vaikuttavuus voi ainakin kokijansa mielessä muodostua elämänkaarta linjoittavaksi. (7) Lukukokemukseni perusteella tutkimus edistää aikuispsykologisen tutkimuksen irtaantumista kliseisestä postmodernissosiologisesta liturgiasta. Merkittävä ansio siis - vai onko sittenkään?

Juha Varila 